\title{
COMMENTARY /
}

\section{A PERILOUS PATH TO PRIVATIZATION?}

\section{by Bernard Dixon}

$\mathrm{E}$ xactly a decade ago, Britain's Microbiological Research Establishment (MRE), based at Porton Down near Salisbury, became thoroughly civilized. A Ministry of Defence station until that time, charged with maintaining a defensive capability against attack by biological weapons, MRE was transferred to the Public Health Laboratory Service (PHLS) and became known as the Centre for Applied Microbiology and Research (CAMR). Less only a small team of microbiologists who were transferred to the nearby Chemical Defence Establishment (the actual number is an Official Secret), CAMR has since consolidated a worldwide reputation for the quality of its work. Directed by Peter Sutton, and with a staff of 650 (about 100 of them science graduates), CAMR ranges widely in its research, focusing particularly on the diagnosis, treatment, and prevention of bacterial and viral diseases.

Now, ten years on, there is at least one new question mark over the future of Porton Down. Notwithstanding the excellence of its work, CAMR is being sized up for privatization. As part of Mrs. Thatcher's phrenetic drive to instill the commercial imperative even more forcefully into the world of science, the government is considering the option of selling off CAMR to the private sector. Some years ago, Mrs. Thatcher and her colleagues considered and then rejected the possibility of privatizing other parts (and indeed the whole) of the PHLS. But CAMR, with its extensive biotechnology expertise and unrivaled fermentation facilities, would be a prize purchase. Just like the National Engineering Laboratory at East Kilbride in Scotland, which is currently becoming a government-owned company in preparation for privatization, CAMR seems set for opening bids.

There is, however, a curious snag about this scenario. Four years ago, one company, Porton International, was given exclusive rights to CAMR's products and processes, in exchange for royalties on sales. Indeed, that agreement was signed after the government's earlier examination of the privatization option. Although ICI, Wellcome, and several other major firms expressed interest in taking over CAMR, the government decided instead to consummate a link with Porton International, established in 1982 by Wensley Haydon-Baillie. How, then, could CAMR now be sold to any other company?

While that question is more than a little difficult to answer, the new situation inevitably focuses attention on the strengths and weaknesses of Porton International and on its relationship with CAMR. No one who has met Mr. Haydon-Baillie can be in any doubt about his vigor and panache, which are amply confirmed by the public record. Before going into biotechnology and pulling off the spectacular CAMR deal, he had, for example, quintupled the turnover of the electrical engineering company Watshams from $£ 5$ million in 1982 to $£ 25$ million in 1986 . Since 1982, moreover, Porton International has received some $£ 76$ million from enthusiastic investors. They range from ICI and the Legal and General Assurance Society to the pension funds of Barclays Bank and British Telecom. An additional strength is the diversity of Porton International, which is not a single entity but a group with interests spanning many different facets of biotechnology and nine different companies. Among others, it owns Speywood Laboratories, a world leader in blood products; LH Fermentation, Britain's major manufacturer of bioprocessing systems; and Omec International, the Washington, DC-based company specializing in information on patents and licensing. Porton International has also been recruiting major talents from the pharmaceutical industry over the past year-not least the highly regarded John Burke, former Chairman of Glaxo Pharmaceuticals and former Chairman of Merck Sharp and Dohme's U.K. division, who has taken up the post of Chief Operating Officer. Mr. Haydon-Baillie (who sold some of his Porton International shares to financial institutions in 1986 for about $£ 24$ million) has good reasons to feel proud of his dedicated achievements in building up the company to its present position.

Unfortunately (though understandably in the neverentirely-predictable world of bioindustry) Porton International has not yet reached its anticipated profitability. The company showed pre-tax profits of only $£ 6.7$ million in 1987 and $£ 5$ million last year, and anticipates a figure of $£ 6$ million for 1989. In the years ahead, there are high expectations of healthy returns from a variety of products, ranging from an anti-leukemic drug to a diagnostic kit for monitoring blood potassium. But the principal money-spinner could be a novel vaccine to prevent recurrent herpes, for which there is a potentially huge market. The problem here is that it has taken at least two years longer than expected to bring this product to the marketplace. Based on work by Gordon Skinner at the University of Birmingham, the vaccine is now in double-blind trials in Chicago and Houston, and the code is expected to be broken around the end of this year.

As well as having a considerable reputation for his bedside manner, Skinner is a highly original thinker, who startled participants at the 14th International Congress of Microbiology, held in Manchester three years ago, by suggesting that herpes might be treated by infecting host cells with a second organism followed by its antibody, thereby preventing the release of herpes virus. The new vaccine (a mixture of viral proteins and glycoproteins, made by growing the organism in human diploid cells) is much more conventional. Why, then, should it solve a problem that seems to have defeated companies such as Merck Sharp and Dohme? How, indeed, can it be expected to prevent herpes from recurring when natural antibodies fail to do so? If such niggles are rendered obsolete by practical triumphs in Chicago and Houston, Porton International could be seen making its giant leap forward. But how all of this relates to the privatization of CAMR remains an extremely difficult question, one that the British government must address by the end of the year. 